\title{
Michigan Sustainability Case: Revisiting the Three Gorges Dam: Should China Continue To Build Dams on the Yangtze River?
}

\author{
Chun Yin Anson Chang, Zhanyang Gao, Amanda Kaminsky, and Tony G. Reames
}

\section{Introduction}

Michigan Sustainability Cases (MSC) is an initiative of the University of Michigan School for Environment and Sustainability producing case studies for sustainability education that presents its cases on an inclusive openaccess learning platform called Gala. Each case tells the story of a controversial real-life issue with a challenging decision to be made, accompanied by audiovisual resources and an engaged learning exercise. Learners analyze the case by considering the interactions between the decision maker and main stakeholders. This case explores the largest hydroelectric power station in the world, the Three Gorges Dam.

Hydroelectric power is renewable, clean, and contributes to the reduction of greenhouse gas emissions. Building a hydroelectric dam, however, is a massive political and economic undertaking, with substantial consequences for both upstream and downstream communities and ecosystems.

The Three Gorges Dam, which opened in 2009, provides power to millions of people across China and has created countless jobs and development op- portunities. Weighing these benefits against the dam's negative social and environmental impacts, this case explores: 1.) the unique legal and political context of dam building in China; 2.) the dam's geological externalities, including increased earthquake and drought risk; 3.) ecological damage, including the endangerment of many terrestrial and freshwater species; and 4.) the involuntary resettlement of millions of displaced people. These impacts were further complicated by the government's funding scheme, which relied on subsidies paid by the total population of households and companies in China, despite only a small portion of the population directly benefiting from the dam.

This case offers a retrospective examination of the Three Gorges Dam, with the intent of guiding decision making regarding a recent proposal in China to build similar dams on upstream portions of the Yangtze River. Students would be expected to learn about evaluating the clean-energy benefit and socio-environmental impacts with the Energy Justice Framework, which guides toward making a final decision on the new proposed dam.

\section{Chapter 1}

\section{Mr. Wu's Decision}

One morning in winter 2015, at a polished mahogany desk in an office in Zhongnanhai, Beijing, Mr. Wu Youren, the special assistant on sustainable development to Mr. Xi Jinping, the General Secretary of the Chinese Communist Party and China's president, paused with his pen poised between two different proposals. The first, from China's National Development and Reform Commission, proposed a string of new hydroelectric dam construction projects on the Jinsha River, the headwater of the Yangtze River, to bolster the country's manufacturing capabilities and its ability to accommodate rapid urbanization with more clean power. The second proposal, coauthored by the Chinese Ministry of Environmental Protection and several provincial governments downstream of the Three Gorges Dam, urged the central government to cease building new dams going forward, and instead to prioritize ecosystem conservation along the Yangtze River and its surrounding areas.

These two proposals reflected two conflicting development futures. If

School for Environment and Sustainability, University of Michigan, Ann Arbor, Michigan.

(c) Chun Yin Anson Chang et al., 2018; Published by Mary Ann Liebert, Inc. This Open Access article is distributed under the terms of the Creative Commons Attribution Noncommercial License (http://creativecommons.org/licenses/by-nc/4.0/) which permits any noncommercial use, distribution, and reproduction in any medium, provided the original author(s) and the source are credited. 
the dam proposal were rejected, China would forfeit a wealth of alternative renewable electricity and a much-needed boost to the rural economies of the provinces that would host the planned new dam sites, including Tibet, Yunnan, and Sichuan. But at the same time, approving the dams would carry many social, ecological, and even political risks for not just the communities directly affected by dam building, but the whole country.

Before Mr. Wu made his recommendations to President $\mathrm{Xi}$, he wanted to look back at the history of the Three Gorges Dam, the world's largest power station, completed in 2006 and put into full operation in 2009. By reviewing the original goals of the Three Gorges Dam (TGD), the decisionmaking process leading up to its construction, and the project's environmental, social, and economic impacts, $\mathrm{Mr}$. Wu believed he could gain wisdom and insight. Looking out the window at the beautifully frozen Zhongnanhai Lake, Mr. Wu tried to order his thoughts and remember the various perspectives of many ministers and advisors.

\section{Political Background}

As the General Secretary of the Communist Party of China and China's president, Xi Jinping (Figure

1) has enthusiastically supported environmental protection and sus-

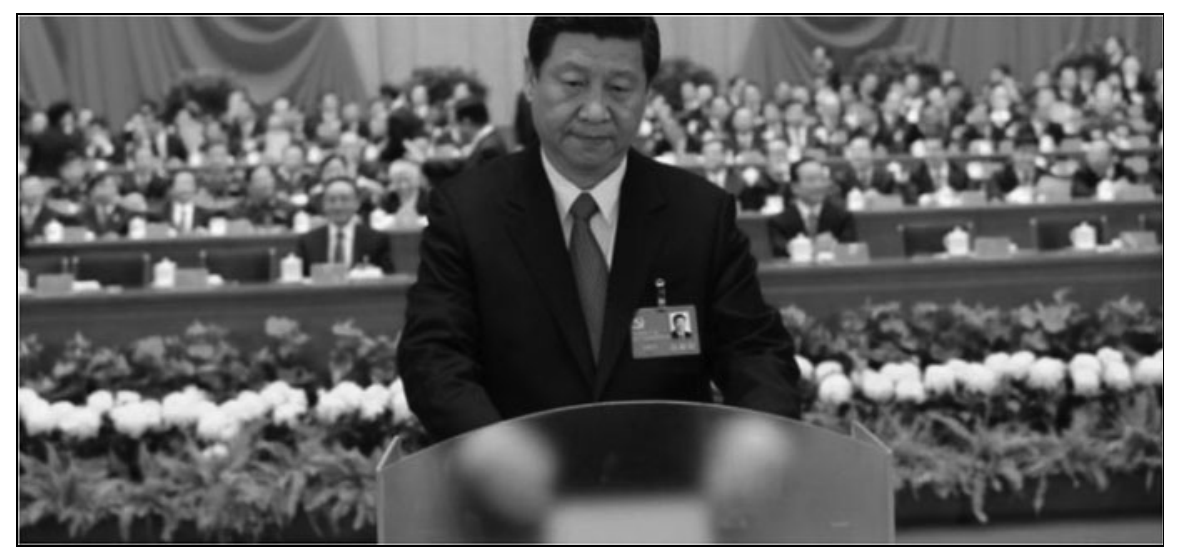

Figure 1. Xi Jinping, President and General Secretary of the Communist Party of China tainable development since he became China's leader in 2012. He has called for more efforts to promote green development and green lifestyles as the country seeks to better balance economic growth and environmental protection. In a speech, $\mathrm{Xi}$ said the country should protect the environment "as one protects one's eyes" and treat the environment "as one treats one's life." He said: "China should firmly reject development models that damage or destroy the environment and bid farewell to practices that boost short-term economic growth at the cost of the environment."

At the same time, Mr. Xi Jinping has also dedicated significant effort to addressing long-standing issues of injustice in China, especially the extreme poverty in rural areas. He described eradicating poverty by 2020 as one of his chief priorities, vowing to "leave no one behind in the march toward common prosperity."

As the special assistant on sustainable development to $\mathrm{Xi}, \mathrm{Mr}$. Wu Youren had more than 20 years' experience in provincial and central government. His unique educational background, with an MBA and an MS in Environmental Science from the University of Michigan, offered him multi-angle views on China's sustainable development strategy.

Unlike in many other countries, decision-making authority in China ultimately resides solely in the top leadership of the Chinese Communist Party (CCP). Although the CCP is complexly interrelated with the central government, which is embodied in the State Council of China, the party itself is where decisions are made.

The Chinese Communist Party, which had 82.6 million members as of 2015, is headed by the Standing Committee of the Political Bureau (known as the Politburo), a group of seven to nine people who oversee the party. Although each member of the Standing Committee has a vote when making big decisions, the General Secretary of the Communist Party of China, currently Xi Jinping, has a big influence over the result.

Once the important decisions have been made by the Politburo, the State Council and the 25 ministries under its supervision, within which most officials are members of the CCP, will execute these decisions. These 25 ministries include the National Development and Reform Commission, which has broad administrative and planning control over the Chinese economy, and the Ministry of Environmental Protection.

The National People's Congress (NPC) is the national legislature of China. Under China's current Constitution, the NPC is structured as a unicameral legislature. In theory, the NPC is the highest organ of state power in China, with the power to legislate, the power to oversee the operations of the government, and the power to elect the major officers of the state. However, in practice, almost 100 percent of the NPC members usually just vote for each decision already made by the CCP. 
Even so, when the National People's Congress approved the Three Gorges Dam in 1992, 1,767 out of 2,633 delegates voted in favor of the dam. There were 177 votes against, 664 abstentions, and 25 members did not vote. It was very rare for so many delegates to fail to support a project.

During the 1990s, there were no nongovernmental organizations (NGOs) active in China. Community involvement in governmental decisions was also extremely rare, even in cases where the entire community was affected by a given policy or proposal. Since 2000, as people's awareness of property rights, pollution, and environmental degradation has increased, more and more NGOs focusing on environmental protection and human rights have developed rapidly in China.

\section{Chapter 2}

\section{China's Dam-Building Dreams}

The Yangtze River originates from the Tibet Plateau and flows 6,380 kilometers (3,964 miles) eastward into the East China Sea. It is the longest river in Asia and the third-longest in the world. The entire river basin has an elevation decreasing from 5,000 to zero meters $(16,000$ to zero feet) and covers a latitudinal range of about $25^{\circ}$ $\mathrm{N}$ to $35^{\circ} \mathrm{N}$. The climate in the Yangtze River basin is strongly controlled by the subtropical monsoon climate in the southeast Pacific Ocean and the Indian Ocean, which has caused over 200 serious floods since 185 BCE. Although the plains in the middle and lower reaches of the Yangtze Basin have been continually menaced by flood hazards, this region has also been home to nearly one-third of the country's population of 1.3 billion, with flourishing sites of agriculture and industry.
China has been constructing advanced hydraulic technology projects for centuries, beginning in 598 BCE with the Qebei Dam in the region that is now Anhui Province. However, in 1949, the year of the foundation of the People's Republic of China, only 22 large dams with an installed hydropower of $163 \mathrm{MW}$ were in service. The original idea of constructing a dam on the Yangtze River came from Sun Yat-Sen, the first president of the Republic of China, in 1919. In an article called "A Plan to Develop Industry," Sun YatSen mentioned the possibility of building a large dam in the Three Gorges area, which is in the middle of the Yangtze, for the purposes of flood control and electricity generation. Unfortunately, due to several historical reasons, including the Second Sino-Japanese War and the Chinese Civil War, the project was postponed. However, tremendous floods on the Yangtze in 1931, 1935, and 1954, which caused 330,000 deaths and displaced millions of people, kept the project on the government's radar.

Another reason for constructing the Three Gorges Dam was power generation. The market economic reforms introduced by Deng Xiaoping in the years since 1979 emphasized the necessity to produce more electric power to enable economic growth. In the mid-1980s, power shortages forced many Chinese factories to operate at 70 to 80 percent capacity, and blackouts became very common in urban areas. The construction of coal power plants was promoted as the primary solution to provide energy in the short term; however, while most coal reserves are located in the north and northwest of the country, most manufacturing is in the east and south, putting huge pressure on China's undeveloped transportation system. Furthermore, the high levels of pollution associated with the coal-burning process escalated the need to find alternative sources of energy. Hydropower in the Three Gorges, which has the potential capacity of 80 billion KWh/year, is a much cleaner source of energy and began to be regarded as a middle- and long-term solution to the issue of chronic power shortages.

Navigation was the third potential benefit provided by the Three Gorges Dam. The Yangtze is a major eastwest artery of China's transportation system. The 660-kilometer stretch from Chongqing to Yichang, where the Three Gorges region is located, has rather poor navigation conditions due to sharp bends, narrow channels, shoals, and rapids. The huge reservoir behind the Three Gorges Dam would drown out most of these natural hazards, thus greatly advancing the development of river navigation in this region.

China's dam-building dreams on the Yangtze River sprang from three major social needs: flood control, electricity generation, and navigation. Hundreds of thousands of people have died as a result of regular flooding of the Yangtze River every few decades. For the past century, these tragedies have led generation after generation of Chinese politicians to dream about damming the river. While power generation is, therefore, an important aspect of the Three Gorges Dam, flood control has been the primary objective since the dam's conception.

\section{Chapter 3}

\section{Controversies in the Decision-Making Process}

To $\mathrm{Mr}$. $\mathrm{Wu}$, the benefits of flood control, power generation, and 
navigation looked highly appealing. However, he understood that the controversies surrounding the Three Gorges Dam had made its approval a highly complex and difficult decision for China's top leadership during the early 1990s. The government's concerns included:

\section{The size of the project. The} proposed Three Gorges Dam was unprecedented in China's modern history. The conservative estimate of dynamic construction cost (adjusted with inflation and interest cost) was $¥ 200$ billion (U.S. $\$ 29$ billion), with the exchange rate $8: 1$ at that time) and the construction would take 18 years to complete. Given that the GDP per capita in China was just $\$ 419$ in 1992, the project would become a heavy load on the shoulders of each Chinese citizen.

2. The risk of silt build-up, leading to upstream flooding. Because of the lack of trees in the mountainous upstream regions of the Yangtze, massive volumes of silt flow downstream. As deforestation and development increase, the sedimentation has increased to 700 million tons annually since the commission and counting. Without the swift current to carry this silt out to sea, it was feared that silt would build up behind the dam, raising the upstream riverbed, and eventually shortening the life expectancy of the planned reservoir. In order to flush silt through, engineers have designed a series of openings known as sluice gates at the base of the dam. However, sluice gates have never been tested on a dam of this magnitude. With such a venture into unfamiliar engineering territory, the city of Chongqing, upstream of the dam, an urban center with over 10 million people, would be in danger of catastrophic flooding.

3. Widespread human displacement. After completion of the dam, the water level was predicted to rise to over 500 feet, creating a reservoir nearly 400 miles long where once there were thriving communities. Over 1.3 million people would have to be resettled, entailing not only a change of residence but also a substantial modification of their livelihoods. Many of these people would be forced to move to steeper slopes, with poorer soils and decreased agricultural income potential.

4. The loss of archaeological and cultural heritage. The Three Gorges region has been home to uninterrupted settlement since prehistoric times. Many different cultures have inhabited the place that would be submerged by the reservoir, such as the Daxi (ca. 5000-3200 $\mathrm{BCE}$ ), which was the earliest Neolithic culture in the region. Fengdu Ghost city, a historical city known for its large complex of shrines, temples, and monasteries dedicated to the afterlife, would also be submerged by the reservoir.

5. Loss of biological diversity. There are over 300 species of fish in the Yangtze River, along with countless plants, insects, mammals, and other organisms. The dam would create a barrier in the river, preventing fish from traveling upstream to spawn. The temperature and flow rate of water would no longer be adjusted only by the natural cycle, but would be artificially controlled in order to regulate water storage and discharge. For a fish adapted to breeding in slow-moving water, the rapid flow caused by a sudden release from the dam would wash away the spawn, with devastating effects to the species. The habitats of many endangered species such as the Yangtze river dolphin, the Yangtze sturgeon, and the Siberian crane would be destroyed as well. The government planned to sustain the Yangtze river dolphin and other endangered species by creating natural reserves and artificial spawning programs; however, past attempts to relocate the Yangtze river dolphin have failed, and the species is today considered extinct in the wild.

China's top decision makers were well aware that the project would be a double-edged sword. If everything ran smoothly, the dam could become a monument in memory of their great achievements. But if anything went awry, or if the dam's disadvantages came to outweigh its advantages in the eyes of the nation and the world, resource scarcity, political instability, and other disasters could result. Although the Chinese government ultimately decided to move forward with the construction of the TGD, $\mathrm{Mr}$. Wu knew that the actual decision-making process was opaque and highly political. From the point of view of the West, political decisions in China are typically made far from the public eye. From 1986, when the government first started assessing the feasibility of the dam, until 1992, when the Politburo Standing Committee and 
National People's Congress (NPC) formally approved the project, over 400 experts from different disciplines and countless officials were involved in evaluation and discussion of the project. While support mainly came from officials in the CCP and government, most of the opponents were eminent scholars and experts. These opponents not only expressed deep concerns about the TGD but also criticized the decision-making process itself for its lack of due process and procedural justice. This criticism included:

1. Conflicts of interest within the feasibility study group. The feasibility study was organized by the Ministry of Water Resources and Electric Power, which openly advocated for the TGD. When selecting the members of the feasibility study group, more than half of those selected were either employees of the Ministry or had a close working relationship with it; many well-known experts, meanwhile, were excluded.

2. Manipulation of findings. In the conclusion of the feasibility study, unfavorable evidence and reasonable concerns were excluded. Even some key data, like the project cost estimates and the number of people to be resettled, were deliberately altered to make the proposal more appealing.

3. Political pressure to approve the dam. Some experts who signed the final report that was submitted for approval admitted that they had done so under pressure from the authorities. "You must keep the overall interests of the country in mind and accept the organizational arrangements!" an expert recalled an official telling him.
4. Lack of local input. The authorities ignored the needs and desires of the over one million people living near the dam site, most of whom stood to lose the homes they had lived in for generations.

5. Lack of informed opinions in the final vote. Of the 2,600 delegates who voted to approve the dam, few had enough background knowledge to effectively evaluate the proposal. Very little time was given to review and discuss the report before proceeding to the final vote.

Despite these controversies, the Three Gorges Dam project was approved. Construction began in 1993 and was finally completed in 2006.

\section{Chapter 4}

\section{Reviewing Trade-Offs \\ Construction of the dam}

Mr. Wu still remembered how shocked he had been when he saw the completed dam in 2009. "It is one of the greatest legacies of human civilization!" he said to himself. With its 2.3-kilometer (1.4-mile) length and 185 -meter (607-foot) height, it creates an upstream reservoir that can hold 39.3 billion cubic meters of water (Figures 2 and 3 ). This capacity is theoretically great enough to withstand once-a-century flooding from upstream. The gargantuan infrastructure provides a total generation capacity of 22,500 megawatts, more than three times the capacity of the Grand Coulee, the largest dam in the United States (Figure 4). In total, the TGD produces 84 terawatt-hours of electricity annually, which is more than four times the energy produced by the Grand Coulee.

Follow this link to view a video describing TGD and its construction: https://www.youtube.com/watch?v= b8cCsUBYSkw (24:34 mins, for abbreviated version view from 2:23-9:14).

In order to help ships navigate the dam, the Chinese built the biggest

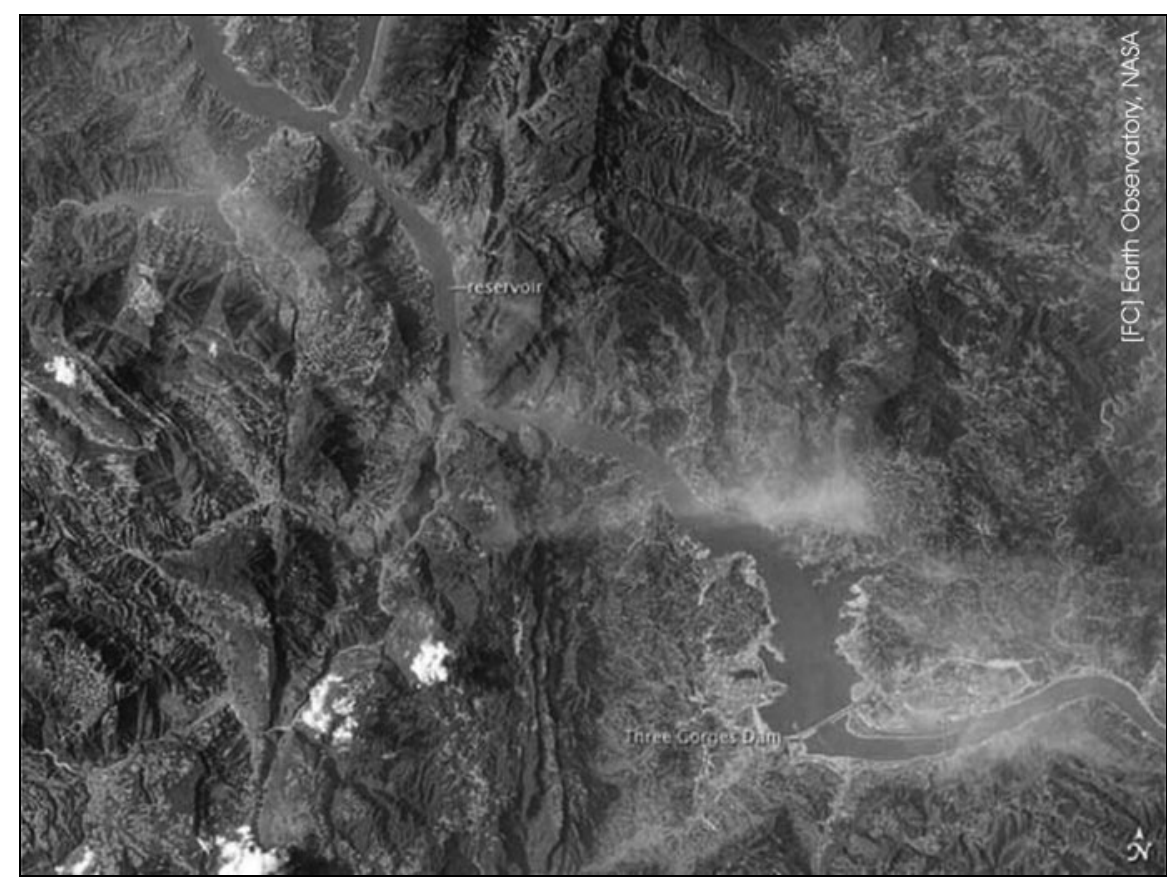

Figure 2. Aerial view of Three Gorges Dam from space 


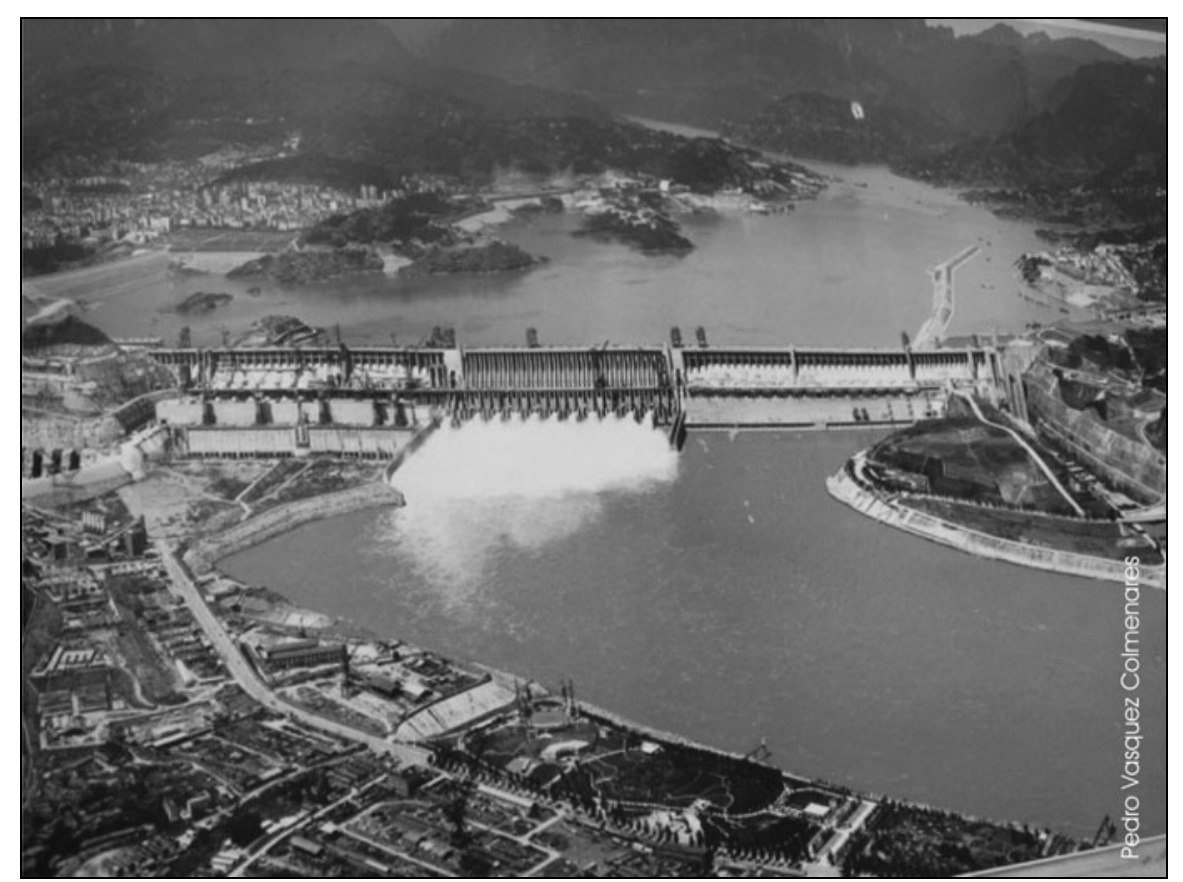

Figure 3. Full view of the Three Gorges Dam.

system of ship locks on earth. The five tiers of locks, which are 280 meters long, 35 meters wide, and 5 meters deep, may take up to four hours to transit ships from under the dam to the top. This length of time was too burdensome for the passenger ship industry, so engineers built a 113-meter (370-foot) ship elevator. This lifting system allows boats as heavy as 3,000 tons to

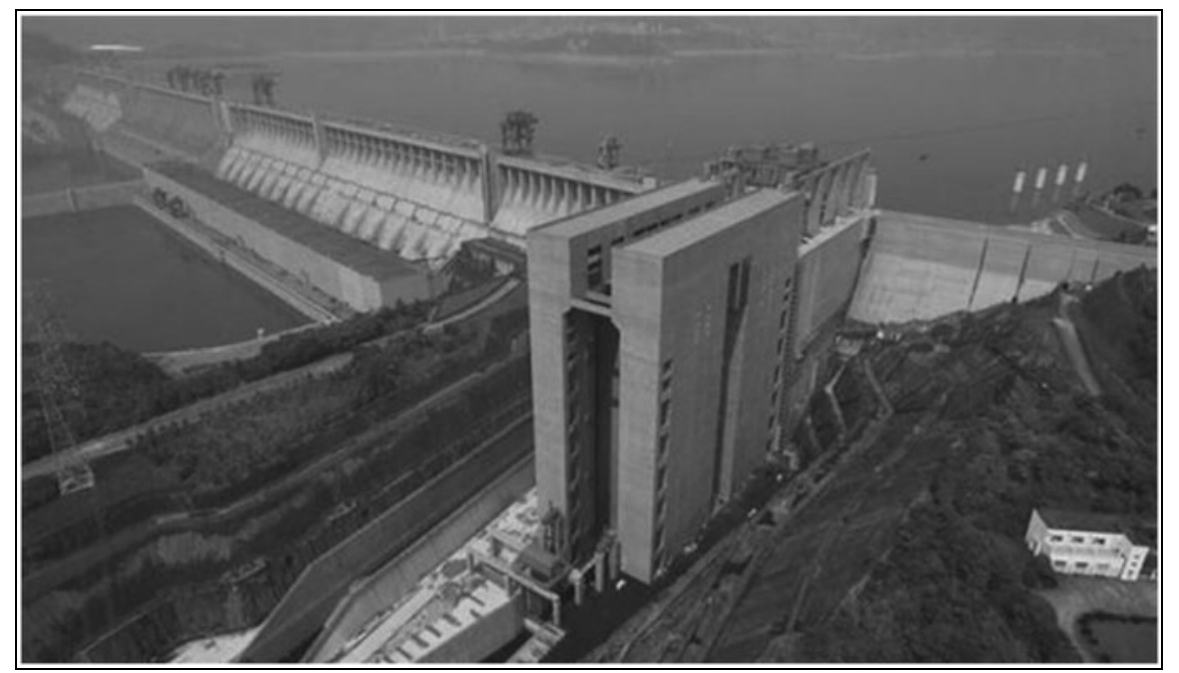

Figure 4. Grand Coulee Dam, Columbia River, Spokane, Washington

pass through the locks in about 36 minutes.

To view a demonstration of the TGD ship lock, watch this video showing two of the five stages: https://www .youtube.com/watch? $=$ =pdUeBD9nk3g (2:19 mins).

$\mathrm{Mr}$. Wu sat in his office, checking reports to see whether the estimated benefits and impacts of the TGD had become reality. As an experienced politician with an educational background in environmental science, he realized that some unexpected results were inevitable given the dam's size, and given the complex natural and environmental conditions of the Yangtze River, which was so essential to more than 500 million people and countless wild animals and plants.

The flood control function had seemed to work well: There had been no major flood disaster downstream after the dam was completed. While many experts have attributed the lack of flooding to the dam's ability to withstand once-in-a-centurymagnitude floods, Mr. Wu noted that some experts worried that only time will tell and that the dam's capability had simply not been truly tested yet.

The power plant had proven to be a cash cow, as expected: It had generated 85 billion kilowatt-hours of electricity, equal to RMB 22.3 billion in revenue each year. (The unit price is 25 cents for one kilowatt-hour.) As of the end of 2013, the dam had generated 700 billion kilowatt-hours, worth about RMB 182 billion. At the same time, the dam reduced coal consumption by 31 million tons per year, avoiding 100 million tons of greenhouse gas emissions as well as the production of millions of tons of dust, one million tons of sulfur dioxide, 370,000 tons of nitric oxide, 10,000 tons of carbon monoxide, and a significant amount of mercury. As an official determined to promote China's Green Development, $\mathrm{Mr}$. Wu understood the great achievements of the dam.

Navigation had also improved considerably after the dam was completed (Figure 5). The water level in the reservoir increased to 156 meters, which widened the waterway to twice its 


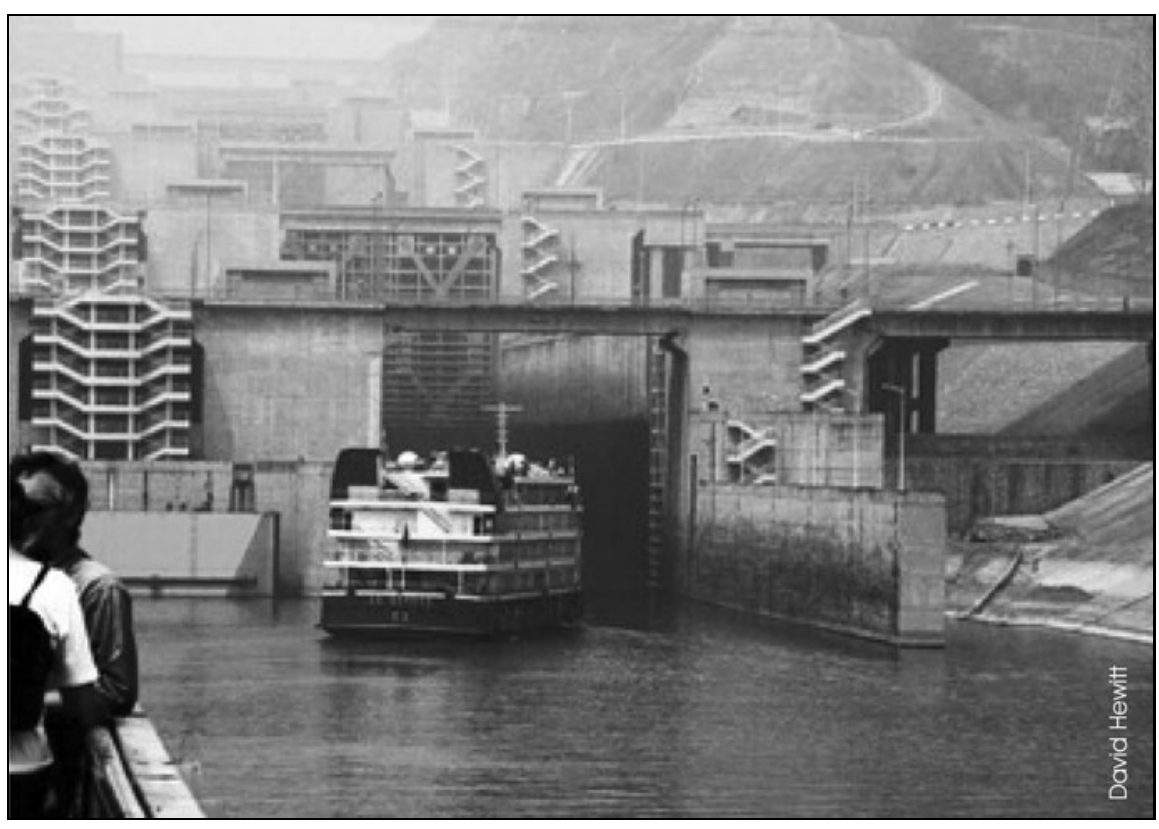

Figure 5. Locks allow barges to bypass the dam.

original width, thereby meeting the needs of the ten-thousand-ton fleet of ships transporting cargo between Wuhan and Chongqing. However, because the engineers did not anticipate such a large increase in traffic volume, many ships now had to wait days before passing through the fivelevel ship lock.

After the project was formally approved in 1992, the state estimated it would cost 203.9 billion yuan (\$29.6 billion), over twice the amount originally proposed in the report. But the total infrastructure, including the dam itself, the giant lock for carrying ships up and down the river, and 26 power generators, had a final price tag of 184.9 billion yuan ( $\$ 26.8$ billion) when it was completed in 2009. Finding new homes for people whose towns and villages were flooded cost an additional 69.3 billion yuan ( $\$ 9.9$ billion), bringing the total to about 254 billion yuan ( $\$ 36.9$ billion). This price tag did not worry the government, given China's rapid economic growth during the 1990s and 2000s. Indeed, a big portion of these funds had come not from any private investor or government bond, but instead from the Three Gorges Dam Construction Fund, which is funded by a levy on each household and company in China. In 1992, when the dam was approved, a meeting of the Prime Minister's Office of the State Council decided that a levy of 0.003 cents on every kilowatt-hour of electricity consumed nationwide would be used to provide additional financing for the project. In 1994, the levy was raised to 0.004 cents on every kilowatt-hour consumed. In 1997, it was raised again to 0.007 cents in 16 provinces and major cities. Between 1993 and 2009, the fund collected an estimated total of 103.4 billion yuan ( $\$ 15$ billion) from individual Chinese citizens and companies through their electric bills. However, these consumers did not necessarily receive the cheaper electricity promised by the government once the dam was built. Most of them remained unaware of exactly how big this accumulated capital was, and how exactly it had been utilized.
$\mathrm{Mr}$. Wu noticed with alarm that geologists were predicting that more frequent catastrophes were likely to occur in the TGD region. In September 2014, a landslide destroyed the Lifengyuan Hydropower Station, which is close to the dam; the event left dozens of people dead. A report from Sichuan Province's Geology and Mineral Bureau identified over 5,000 danger points, including collapses, landslides, dangerous cliffs, and banks. Behind these danger points was the giant 600 kilometer long reservoir created by the dam, the water level and expanse of which always change throughout the year. Mr. Wu saw two worrying consequences: First, the banks of the reservoir were subject to frequent changes, increasing the chances of landslides. Second, the huge lake influenced the local climate, making extreme weather events, particularly cloudbursts and heavy rain, more likely.

The water level in the reservoir hit its peak height of 574 feet (175 meters) in October 2010, as part of an effort to maximize electricity production. This led to several unexpected problems. First, the large, shallow lakes that form flood basins in the middle Yangtzeparticularly Boyang and Dongting Lakes, the two largest freshwater lakes in China-were lower than usual and had dried up dramatically, exacerbating local hardships. While the TGD operators attributed this to the dry weather, many believed that, in fact, the TGD operators had unethically resisted releasing drought-relief water from the dam in order to maintain maximum power generation (and monetary gain). The problem was solved temporarily by the central government's order to open the floodgates and send 3.7 billion tons of water (about 10 percent of the reservoir capacity) downstream. But this incident led many people to realize that the huge influence of the dam stretched far beyond its limited local 
region, affecting the middle and lower reaches of the Yangtze and the homes of hundreds of millions of people. Some scientists have even raised fears that the devastating Wenchuan earthquake in China in 2008, which killed about 70,000 people, was caused by the filling of the dam's reservoir, although no conclusive evidence has been presented.

As he read about these issues, Mr. Wu's face became serious. Given the increasing volatility of weather events due to global climate change, $\mathrm{Wu}$ feared that the dam had the potential to exacerbate issues that would directly affect his nation's well-being.

\section{Chapter 5}

\section{Involuntary Resettlement}

In addition to ecosystem services and energy concerns, $\mathrm{Mr}$. Wu was aware that the Three Gorges Dam had directly affected the lives of thousands of Chinese farmers and villagers living near the Yangtze River. He remembered the controversial protests and media reports surrounding the flooding of cities and farmland, the destruction of homes, and the forced resettlement of entire communities. $\mathrm{He}$ feared that a new dam would result in similar social and cultural disruptions, and he knew that his decision must take these risks into account.

The reservoir created by the TGD flooded 156,000 acres of land. Although exact numbers are difficult to obtain, Mr. Wu read that between 1992 and 2008, over 1.3 million residents living in the floodplain of the TGD were displaced and resettled. ${ }^{1}$ Approximately 20 percent of this population was rural and was resettled within the same administrative county. Many of these rural residents were relocated to urban areas. ${ }^{2}$ The majority of displaced people were urban, and most of these were resettled in nearby urban areas or newly built urban centers outside the floodplain. Approximately 125,000 additional urban residents were resettled farther outside the TGD floodplain, often in other provinces. ${ }^{1}$

This mass movement of people was carried out in full accordance with Chinese law, which has a complex system of regulations for involuntary resettlement. $^{3}$ Prior to the TGD project, China had a long history of forcibly resettling people in the wake of development. Since 1949, as many as 10 million people have been removed from their homes to make way for the construction of dams, as well as roads, factories, and other projects. ${ }^{4}$ Most of the resettlement schemes enacted prior to the 1980s were considered unsuccessful since they frequently failed to adequately compensate relocatees and restore their livelihoods. Rural residents, in particular, were found to be subject to increased poverty and decreased well-being following relocation. ${ }^{4}$

Throughout the 1980s, however, policy changes in China gradually led to improved compensation regulations and guarantees for those who were involuntarily relocated.

During the early stages of the TGD project development, new policies were enacted to require economic development of resettled areas in addition to individual and household-level compensation. Termed "development type resettlement"4 or "resettlement with development (RwD),"3 these policies viewed resettlement as an opportunity to develop the infrastructure and economy of the new destination community. This approach was intended to provide displaced persons with higher income levels and a better quality of life than they had before, as well as to boost the economy of the surrounding area. ${ }^{3}$ China's new policies also enacted measures to spread the economic benefits of the TGD throughout affected local communities, including allocation of income and tax revenue from the dam to local communities, preferential employment and tax benefits for local residents, and the provision of loans to local farmers and entrepreneurs. ${ }^{5}$

$\mathrm{Mr}$. Wu could see that the "resettlement with development" approach was enacted with good intentions, and he was pleased to see the international support that it had received. The World Bank considers China's resettlement policies to be a model among developing countries, ${ }^{3}$ all of which are trying to balance the need for infrastructural development with the individual rights and freedoms of their citizen populations. Several recent studies have suggested that resettlement affects people variably, with many of the relocatees better off than they were before. In a study of the social and psychological effects of relocation, the resettled populations were likened to recent immigrants assimilating into any new society, for whom integration and general well-being are gradual processes. ${ }^{6}$ A separate longitudinal study of two resettled communities over a period of eight years demonstrated that conditions significantly improved over time, even for the poorest and most rural relocatees. ${ }^{5}$ Despite "difficulties early on," the relocation project was ultimately considered to have been successful, with credit given to the Chinese government's "exceptional" efforts to equitably and peacefully meet the needs of the Three Gorges communities. ${ }^{5}$ 
As Mr. Wu continued to read, however, his research also revealed a darker side to resettlement with development. In several studies conducted in the late 1990s and early 2000s, resettled populations were found to have higher poverty levels than they did before. ${ }^{3,7,8}$ Rural residents, in particular, suffered after their relocation because of the loss of their farmland. As they were forced higher into the mountains, steeper slopes and poorer soils led to reductions in land assets and crop yields. ${ }^{8}$

Even beyond material wealth, research has found that many of the people who have been involuntarily resettled have had trouble integrating into their new communities. This has resulted in feelings of isolation, the loss of social networks, lack of linguistic competence in the local dialect, and other social and psychological problems. ${ }^{6}$ Forced migration also leads to increased rates of depression and other forms of psychological distress. ${ }^{9}$ The study authors stress that relocated persons are like international refugees in their experience of loss, trauma, chronic stress, and other difficulties adjusting to a new way of life in an unfamiliar place. Taking physical and psychological well-being into account, TGD-related relocation has thus negatively impacted the wellbeing of hundreds of thousands of people.

Such large-scale resettlement has unsurprisingly been controversial both inside China and among international human rights activists. In China, a powerful resistance movement was spearheaded by Dai Qing, a journalist and activist. Dai was arrested and imprisoned following the 1989 publication of her book Yangtze Yangtze!, a collection of essays and interviews with activists in opposition to the Three Gorges Dam. De- spite being banned, this book has been credited with pressuring the State Council to temporarily postpone construction of the dam. ${ }^{2}$ Some scholars credit Yangtze Yangtze! with prompting the Chinese government to engage with NGOs for the first time, and to show some openness to hearing complaints from the public. ${ }^{2}$

Dai Qing's book gave a louder voice to local-level protests that had erupted over the issue of forced resettlement. Throughout the Yangtze floodplain region, rural activists circulated petitions, staged demonstrations, and obstructed construction activities. Several foreign journalists reported news of the resistance, often with legal consequences from the Chinese authorities. Several international NGOs also became involved in the movement against the TGD, including Probe International, the Transition Institute, and the International Rivers Network. ${ }^{2}$ In this way, resistance against the TGD merged with larger international conversations around human rights and environmental justice.

Mr. Wu remembered this social unrest with unease. At the time, the government was able to ignore or suppress these local-level resistance activities with little difficulty. ${ }^{2}$ However, $\mathrm{Mr}$. Wu feared that a new mass protest movement by an uneducated populace could occur in the near future, this time empowered by new media and connected to international partners through the Internet. Such a protest movement would not only threaten public safety, but could also prevent the government from accomplishing projects that would benefit that same populace in the long run. $\mathrm{He}$ understood that there was no simple solution to the sociocultural consequences of large-scale hydroelectric projects.

\section{Relocation issue}

These two videos show some of the issues with relocating a large swath of the population.

Resettlement Footage part 1 https://www.youtube.com/watch? $\mathrm{v}=\mathrm{CTBhGQWfzvI}$ (8:43 mins)

Resettlement Footage part 2 https://www.youtube.com/watch? $\mathrm{v}=$ LeJ7s4Uhutw (8:29 mins)

\section{Chapter 6}

\section{Time To Make the Decision}

$\mathrm{Mr}$. Wu stared at the large map hanging on the wall in his office. The map showed the new proposed system of hydroelectric dams, lined up along the Jinsha River, the headwater of the Yangtze. If these new dams were approved, they would have a total power capacity of 90 gigawatts, or four times the capacity of the Three Gorges Dam. The largest of the new proposed dams, Baihetan, would have a capacity of 16 gigawatts, making it the second-largest hydropower station in the world.

\section{An Introduction to the Baihetan Dam}

The proposed Baihetan Dam would be 300 meters high, above the lower Jinsha River, resting on steep mountains prone to earthquake and mudslides. With 16 giant generators, it could generate 62.4 billion kilowatt-hours of electricity annually, which could provide for the consumption of 5.8 million U.S. households. Although the dam would prevent the burning of 28 million tons of coal, equivalent to 80 million tons of $\mathrm{CO}_{2}$ emissions, over 80,000 people and countless animals and plants would lose their homes forever.

The provincial governments that would host these proposed new dam sites, including Tibet, Yunnan, and 


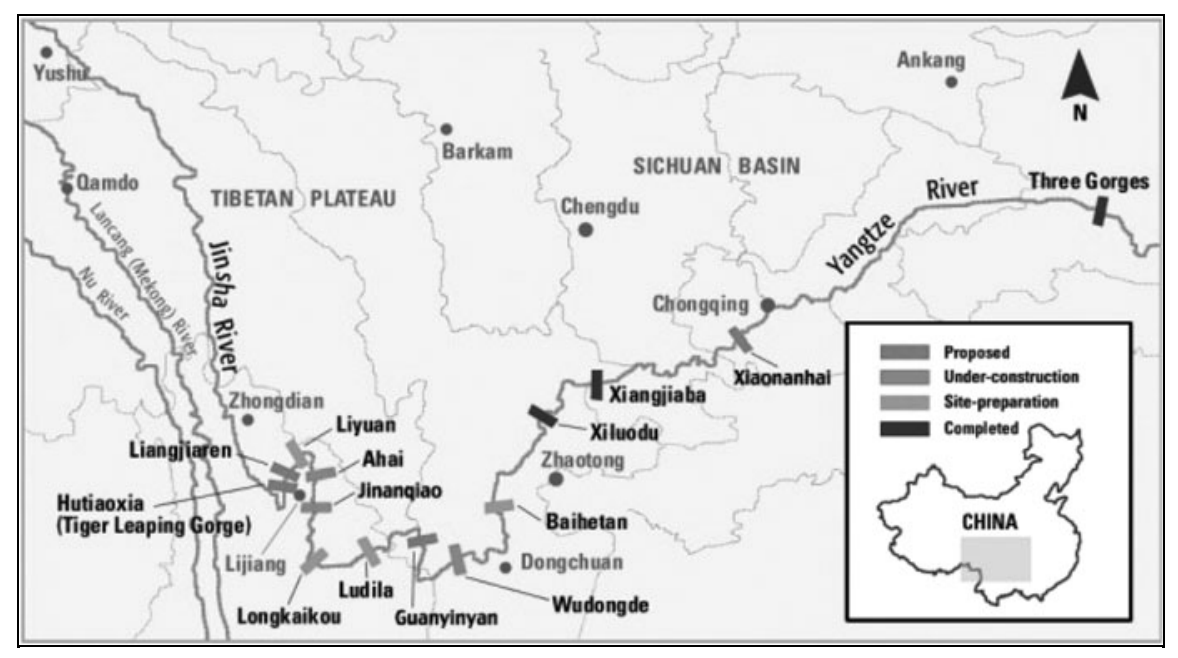

Figure 6. Jinsha Hydro stations

Sichuan, had already expressed great enthusiasm for the projects. These remote provinces welcomed the proposed dams as a once-in-a-lifetime chance to improve infrastructure, boost the rural economy, and lift millions from poverty. Stateowned energy companies, including the one that built and continues to operate the Three Gorges Dam, viewed the new dams as a new cash cow. The National Development and Reform Commission also believed these projects were necessary to bolster the country's manufacturing capabilities and its capacity to accommodate rapid urbanization with more clean power, especially as China was carrying out its promise made in the 2015 Paris Agreement to reduce its carbon intensity by 60 to 65 percent from 2015 levels by 2030 .

However, scientists warned that most of the dam sites were vulnerable to landslides, collapses, and earthquakes. More than 100 rare fish species would be driven to extinction once their spawning grounds were devastated by the dams. Hundreds of thousands of people would lose their homes, and even the best state compensation plans would be able to provide these displaced people only with hilly terrain in the mountains, which would accelerate deforestation in an already fragile region. Most dramatically, if the dams were built, the Yangtze River would no longer flow freely in any part of its natural course. Instead, the entire river would become an artificial canal controlled by engineers who would carefully regulate water storage and discharge. This was widely perceived to be risky, although no one knew for certain how successful such artificial regulation could prove in reality.

Should Mr. Wu advise his superior to approve these new dams on the Jinsha River? If not, could China utilize other renewable energy resources like wind, solar, or biofuel to replace these dams? Compared to hydropower, wind energy is less stable and solar is more costly. Making biofuel from corn, sugarcane, and other agricultural crops typically needs lots of fresh water and land, both of which are limited in China. Several pros and cons of renewable energy are shown in Table 1.

Meanwhile, the proposed dam projects would inject billions of RMB into remote areas that often had very high poverty and poor infrastructure. $\mathrm{Mr}$. $\mathrm{Wu}$ recalled a visit to the Jinsha River where he saw children traveling by zip line to attend classes, lacking any other means of transport (Figure 7).

If $\mathrm{Mr}$. Wu supported the proposal, China would then have to find innovative ways to better balance economic growth and energy production with the protection of the river's unique ecosystems and surrounding communities. Mr. Wu remembered a project initiated by The Nature Conservancy, a U.S.-based NGO, in cooperation with the corporation operating TGD to release flows from the dam that mimic the Yangtze's natural flood cycle in order to promote fish spawning. Inspired by similar projects in the United States, the group also planned to remove some small dams in the tributary of the Jinsha River to create fish passageways.

For the complete text of the interview with the Nature Conservancy's Yangtze Freshwater Advisor, Dr. Qiaoyu Guo, visit: https://www.nature.org/our initiatives/regions/asiaandthe pacific/china/explore/rivers-andwater/qa-yangtze-freshwateradvisor-dr-qiaoyu-guo.xml

$\mathrm{Mr}$. Wu found this to be a comprehensive, basin-scale approach, but he remained unsure how to approach the issue of displaced people. In China, individual people never own the land on which their farms and houses are built; rather, most rural land is owned by local-level government collectives. Legally, then, the government is entitled to use land as it sees fit. But Mr. Wu saw a discrepancy between how the government respects individual rights in urban and rural areas. In big cities like Shanghai and Beijing, governments had to negotiate with each family 
Table 1. Pros and cons of renewable energy

\begin{tabular}{|c|c|c|}
\hline & Pros & Cons \\
\hline Hydropower & $\begin{array}{l}\text { - Has no fuel costs } \\
\text { - Has almost no emissions that impact } \\
\text { the climate and environment } \\
\text { - Provides large-scale and stable } \\
\text { electricity generation } \\
\text { - A hydropower plant has a long } \\
\text { economic life }\end{array}$ & $\begin{array}{l}\text { - Construction has a significant impact on the landscape, river ecosystems, } \\
\text { and even human activities } \\
\text { - Requires huge capital investment and requires more operations and } \\
\text { maintenance }\end{array}$ \\
\hline Wind & $\begin{array}{l}\text { - Has no fuel cost } \\
\text { - Emits no } \mathrm{CO}_{2} \text { across its life cycle } \\
\text { - Can be scaled up easily }\end{array}$ & $\begin{array}{l}\text { - Wind turbines damage the landscape and emit noise } \\
\text { - Intermittent production } \\
\text { - Generation varies by location } \\
\text { - Significant capital cost }\end{array}$ \\
\hline Solar & $\begin{array}{l}\text { - Has no fuel costs } \\
\text { - Can be distributed or large-scale } \\
\text { - Provides reliability when combined } \\
\text { with battery storage and smart software } \\
\text { - Easy to install, requires little } \\
\text { operations and maintenance }\end{array}$ & $\begin{array}{l}\text { - Intermittent production } \\
\text { - Generation varies by location } \\
\text { - Not dispatchable, and possible mismatch between generation and demand }\end{array}$ \\
\hline Biofuel & $\begin{array}{l}\text { - Resources are geographically diversified } \\
\text { - } \mathrm{CO}_{2} \text { emission is significantly reduced } \\
\text { compared with fossil fuels } \\
\text { - Carbon neutral is achievable with } \\
\text { proper management }\end{array}$ & $\begin{array}{l}\text { - Expensive when compared with other energy sources like coal and gas } \\
\text { - Difficult to secure a large amount of resources }\end{array}$ \\
\hline
\end{tabular}

before their houses could be torn down to make way for a construction project. If more than a certain ratio of families in a community said no, the demolition work had to stop. $\mathrm{Mr}$. Wu considered how to give rural people more of a voice in the design and implementation of development plans

that affected them. He wondered, could the urban rules be applied to these dam projects?

Maybe Mr. Wu had a third option beyond a simple yes or no. Perhaps the government should ask for more public comment before making a

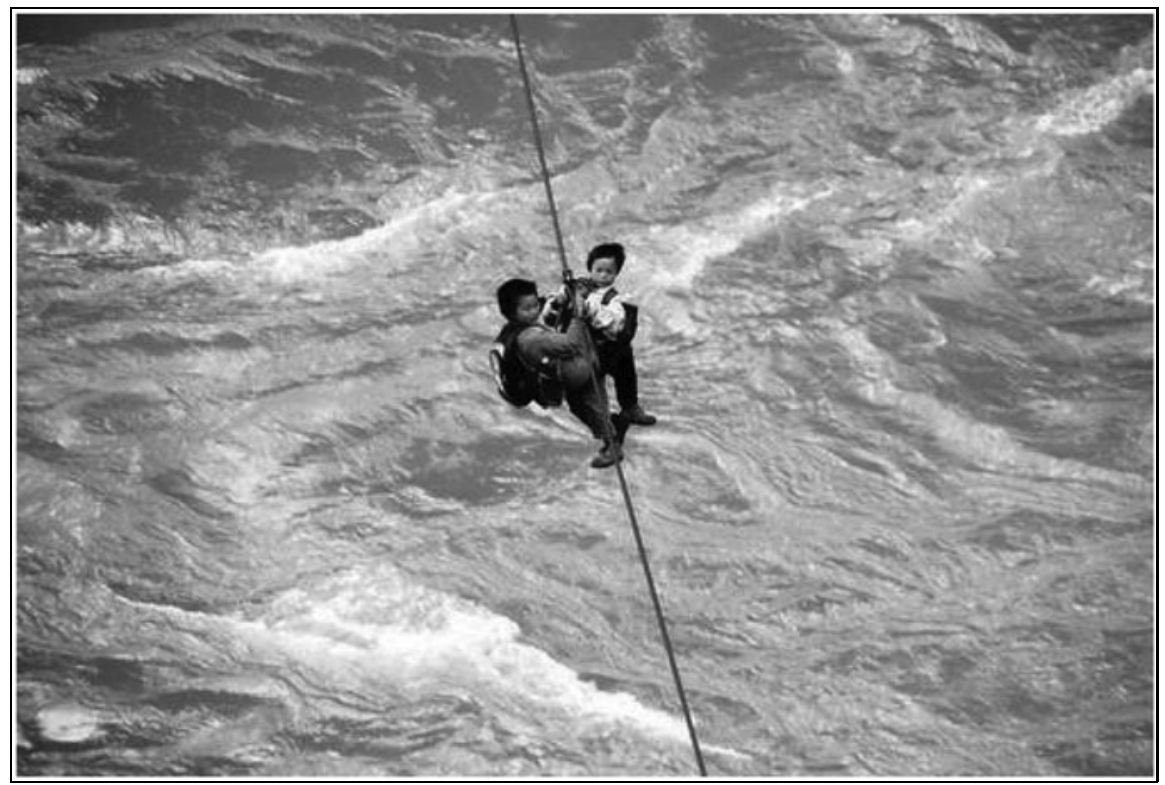

Figure 7. Children using a zip line to get to school across the Jinsha River. firm decision, or perhaps it should seek consultation from NGOs with relevant experience in other contexts. $\mathrm{Mr}$. Wu paused, unsure what to do.

Dear reader: what might your next move be?

Note: The full interactive case study with engaged learning exercises can be found at https://www.learngala .com/cases/revisiting-the-three-gorges$\mathrm{dam} / 10$

\section{Supplemental: Facts and numbers about the Three Gorges Dam ${ }^{10}$}

The TGD is the world's largest hydropower plant.

1. Generation capacity:

- 18.2 million kilowatts

- Annual power generation on average: 84.68 billion kilowatt-hours (kWh) (equivalent to one-seventh of China's total in 1992, four times the total consumption in Los Angeles) 
2. Reservoir inundation:

- 632 square kilometers-the world's largest inundated area associated with a single project, larger than the Grand Canyon

3. Resettlement:

- 365 townships in 21 counties, cities, and districts in Sichuan and Hubei provinces affected

- 844,000 people scheduled for resettlement (with unforeseen factors most likely raising the number to 1.2 million people.)

- 31,000 hectares of farmland and 1,599 companies were inundated with water

4. Project Input:

- 40,000 workers involved, working 24 hours a day, seven days a week

- 17 years of construction in total

- 280 billion USD investment

\section{Author Disclosure Statement}

No competing financial interests exist.

\section{References}

1. Xu X, Tan Y, Yang G, et al. Impacts of China's Three Gorges Dam Project on net primary productivity in the reservoir area. Sci Total Environ 2011;409:4656-4662.

2. Wilmsen B, and Webber M. Mega dams and resistance: The case of the Three Gorges Dam, China. In Grugel $\mathrm{J}$, et al. (eds.), Demanding Justice in the Global South. Palgrave Macmillan, Cham, Switzerland, 2017.

3. McDonald B, Webber $M$, and Yuefang D. Involuntary resettlement as an opportunity for development: The case of urban resettlers of the Three Gorges Project, China. J Refug Stud 2008;21:82-102.

4. Heggelund G. Environmental and Resettlement Politics in China: The Three Gorges Project. Ashgate Publishing, London, 2004.

5. Wilmsen B. After the deluge: A longitudinal study of resettlement at the Three Gorges Dam, China. World Dev 2016;84:41-54.

6. Xi J. Types of integration and depressive symptoms: A latent class analysis on the resettled population for the Three Gorges dam project, China. Soc Sci Med 2016;157:78-86.
7. Jackson S, and Sleigh A. Resettlement for China's Three Gorges Dam: Socio-economic impact and institutional tensions. Communist Post-Communist Stud 2000;33:223241.

8. Tan Y, Bryan B, and Hugo G. Development, land-use change and rural resettlement capacity: A case study of the Three Gorges Project, China. Aust Geogr 2005;36:201-220. 9. Hwang S-S, Xi J, Cao Y, et al. Anticipation of migration and psychological stress and the Three Gorges Dam project, China. Soc Sci Med 2007;65:1012-1024.

10. Embassy of the People's Republic of China in the United States of America. Some Facts about the Three Gorges Project. http://www.chinaembassy.org/eng/zt/sxgc/t36512.htm (last accessed 8/28/2018).

Address correspondence to:

Tony G. Reames, PhD

School for Environment and Sustainability

University of Michigan

440 Church Street

Ann Arbor, MI 48109

E-mail: treames@umich.edu 